\title{
DEVELOPMENT OF A DUAL PURPOSE REFRIGERATION SYSTEM FOR DOMESTIC USE
}

\author{
I. K. Adegun ${ }^{1}$ and O. V. Obasa ${ }^{2, *}$ \\ 1,2 Dept. of Mechanical Engr., Faculty of Engr. \& TeChnology, Univ. of IloRin, ILORIN, KWARA STAte, NigERIA \\ E-mail addresses: ${ }^{1}$ kadegun2000@yahoo.com, ${ }^{2}$ victorobasa78@gmail.com
}

\begin{abstract}
Refrigeration and air conditioning are very important in the daily activities of man, particularly in the tropical regions of the world; used in the preservation of perishable items, storage of pharmaceutical drugs, controlling of an atmospheric environment either for human/animal thermal comfort or effective performance of a scientific process. This paper is aimed at the design and construction of a dual purpose domestic refrigeration system, that can simultaneously function as a refrigerator and as well as an air conditioner henceforth known as REFACON. The refrigeration system employed was a vapour compression system. The machine was a split configuration with an Indoor and an outdoor unit (condensing unit). The machine used a singular 1,119 W single phase hermetically sealed reciprocating compressor, a fabricated condenser and split evaporator operated by temperature controlled solenoid valve. The system used $0.620 \mathrm{~kg}$ of $R 22$ refrigerant, with a discharge pressure of $1,355 \mathrm{kPa}$ and suction pressure of $360 \mathrm{kPa}$. The input power was 1,350 W with an output cooling effect of 5,280 W. The combined cooling load/cooling capacity of the machine was 4,500 W. The results of tests conducted showed a total heat rejected of 6,680 W and a total evaporator heat absorption of 5,179 W. The Energy Efficiency Ratio was 3.91 while the Coefficient of Performance was 4.72. This research has shown that the design employed for the heat exchangers was appropriate and Thermal contact resistance cannot be neglected.
\end{abstract}

Keywords: REFACON, Refrigeration System, Domestic, Coefficient of Performance, Combined Cooling Load, Energy Efficiency Ratio.

Nomenclature

Roman Letters

A: $\quad$ Face area of evaporator $\left(m^{2}\right)$

D: Diameter

f: $\quad$ Pipe Friction Coefficient (A dimensionless parameter obtained from a standard Moody Diagram)

$\Delta \mathrm{h}: \quad$ Change in Enthalpy $\left(\frac{k J}{k g}\right)$

$\mathrm{H}: \quad$ Heat of Compression / Condensation /Vaporization $\left(\frac{\mathrm{kJ}}{\mathrm{kg}}\right)$

m: $\quad$ Mass Flow Rate $\left(\frac{k g}{s}\right)$

P: $\quad$ Pressure $(\mathrm{Pa})$

$q$ : $\quad$ Volumetric flow rate $\left(\frac{m^{3}}{s}\right)$

Q: $\quad$ Heat Absorbed (W)

R22: Chlorodiflouromethane

T: Temperature

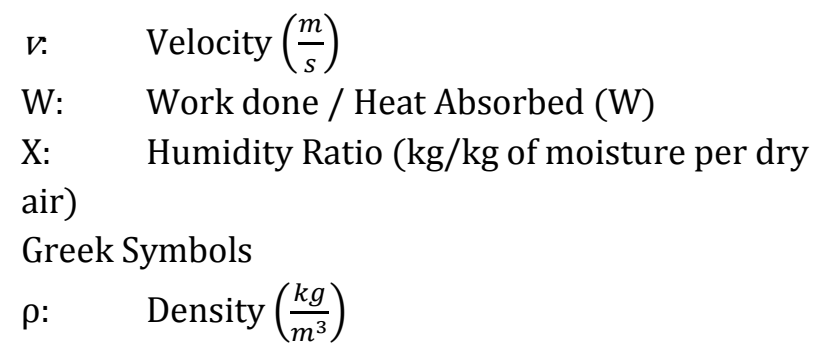

Subscripts

12: Compression

23: Condensation

1a4: Vaporization / Refrigeration Effect

air: Dry air

eff. Effective

cap: Capillary

DB: Dry Bulb Temperature

REF: REFACON

tor T. Ref: Total Refrigerator Load 
face (evaporator): Face of the evaporator perpendicular to the air flow

Abbreviations
ANSI: American National Standards Institute
ASHRAE: American Society of Heating Refrigeration
and Air conditioning Engineers
BSR: $\quad$ Board of Standards Review
CLTD:
CLF: $\quad$ Cooling load temperature difference
CL: $\quad$ Cooling load factor
COP: $\quad$ Coefficient of Performance
EER: $\quad$ Energy Efficiency Ratio
Ra: $\quad$ Rayleigh's Number
RE: $\quad$ Refrigeration Effect

\section{INTRODUCTION}

Refrigeration is the action of cooling and in practice this requires the removal of heat and rejecting it at a higher temperature from within a given space for the purpose of chilling foodstuffs, preserving certain substances (cryogenics), or providing an atmosphere conducive for bodily comfort (air conditioning). Storing perishable foodstuffs, furs, pharmaceuticals, or other items that require cold storage [1]

Air-conditioning is the control of an atmospheric environment either for the comfort of human beings, animals, or for the proper performance of some industrial or scientific processes [2]. It also provides an atmosphere conducive to bodily comfort by altering the temperature or humidity of air or both. It can be assumed that Air-conditioning is as a result of refrigeration.

The principle of the Vapour Compression system employed requires evaporation and condensation to occur when liquid refrigerant is receiving and rejecting the specific enthalpy of vaporization and the specific enthalpy of condensation respectively. These processes are at constant temperature and pressure respectively [3]

Almost all refrigeration systems in the world today employ the vapour compression system. Wolf [4] in 1913 patented a Refrigeration Apparatus that was the first attempt at domesticating the vapour compression system. His work consisted a Motor and Compressor combination that worked both as a pressure pump and as a pressure relief valve to transfer refrigerant. He used Sulphur IV oxide as refrigerant. Betchold and Mellowes [5] in 1915 patented a Cooling Apparatus whose elements were encased in a singular unit as is the case in modern refrigerators. They used a liquid condenser and employed Sulphur IV oxide as a refrigerant. Carrier [6] in 1913 patented a system for maintaining the humidity and air quality inside a factory by the use of atomizing sprays, steam injectors, and fan ducts.

Maniscalco [7] in 1941 patented a Combination Air conditioner and Refrigerator that he claimed could work as both a refrigerator and air conditioner in a domestic kitchen. His work had a 3 valve control system that was manually operated and his condensing unit was kept indoors. This arrangement is counterproductive, as the condensing unit is an additional heat source placed in a location heat is being extracted from. Ledbetter [8] in 1989 patented an Air Conditioning Refrigerator. His work consisted of a freezer that could also work as an air conditioner. It consisted of two vapour compression systems which were both kept indoors and his condenser was water cooled in nature. A machine that possess two vapour compression systems is hardly energy efficient and a water cooled condenser is not feasible in a place where water is scarce.

The work of Wei et al [9] concluded that correlation used in obtaining heat transfer coefficients used for condenser design proposed by Akers et al, showed acceptable predictions for mass fluxes employed in domestic systems. Subramanium, [10] in 2014 stated that the correlation proposed by Gnielinski was very accurate for estimating Nusselt Number of a boiling refrigerant inside a tube used in calculating refrigerant side of the heat transfer coefficient.

Bhatia [11] in 2010also asserted that Cooling Load Temperature Difference/Cooling Load Factor (CLTD/CLF) method "yielded the most conservative result" for calculating the cooling load of a room when compared with other methods for calculating cooling loads.

All the above inventions and studies have provided a valuable insight to the Design and Construction of the Dual purpose Refrigeration system (REFACON Machine). For record purposes, the machine developed in its present configuration, is the very first of its kind. Previous attempts at making a combined refrigerator and air conditioner for domestic use, were not publicized in journals, but were publicized in patents (see [7] \& [8]). Hence, data showing their performance with respect to tests carried out were not found in any record or database at the time of presenting this paper.

The machine uses a singular Vapour Compression system. The condensing unit of the machine is to be 
placed outside the room it cools. The machine uses air cooled/heated heat exchangers as water in some parts is scarce. Akers et al correlation was employed for the condenser design. Gnielinski's correlation was employed for the evaporator design. The cooling load of the machine was estimated using the CLTD/CLF method.

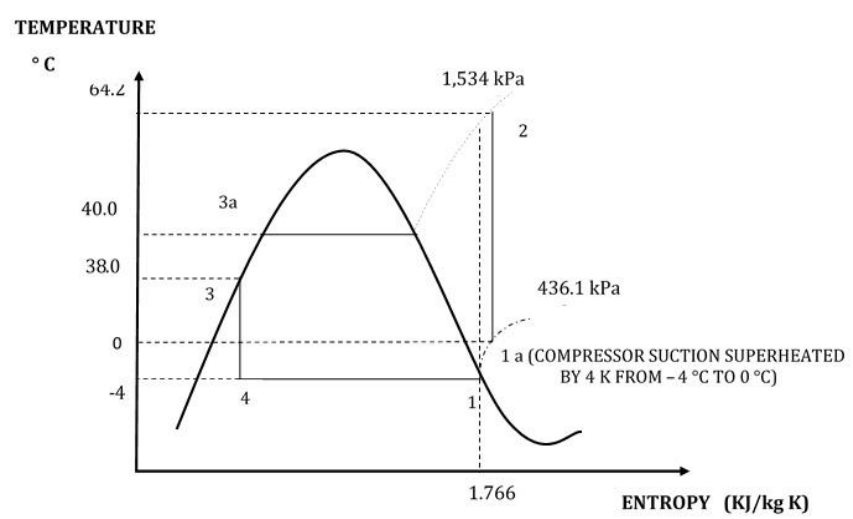

Figure 1: Design/Concept Temperature Entropy Diagram

The problem this paper addressed was the development of a machine that can work as both a refrigerator and air conditioner either simultaneously or independently, the design involved an outdoor unit that improved the system efficiency, used air cooled or air heated heat exchangers. The System used one compressor and one condenser thus saving on production, operation and maintenance.

\section{METHODOLOGY}

\subsection{Design Considerations}

i. The room is to be maintained at $24^{\circ} \mathrm{C}$ dry bulb temperature and 50\% Relative Humidity. These values are chosen using ASHRAE Standard 55 (2004) [12] as a reference which also recommends an indoor operative temperature range of $20-27{ }^{\circ} \mathrm{C}$ at50 \% Relative Humidity. 50 $\%$ is chosen as a value because it is within the acceptable range.

ii. The Air conditioner part of the machine should maintain a room of $21.6 \mathrm{~m}^{3}$ volume at $24{ }^{\circ} \mathrm{C}$ temperature and 50\% Relative Humidity.

iii. The refrigerator part of the machine should attain a minimum design temperature of $-4{ }^{\circ} \mathrm{C}$ and cool a refrigerated space of $0.2 \mathrm{~m}^{3}$.

iv. The design day value used for design of the condenser is $38{ }^{\circ} \mathrm{C}$. A condenser temperature of $40{ }^{\circ} \mathrm{C}$ was assumed. v. Cooling load of air conditioner component of the machine was $3,720 \mathrm{~W}$. This was derived using Cooling load temperature difference method [11].

vi. The tonnage for the refrigerated volume $\left(0.2 \mathrm{~m}^{3}\right)$ of the machine is $773 \mathrm{~W}$. Tonnage can be defined as the amount of heat energy extracted from by a refrigeration system when freezing one short ton $\left(907 \mathrm{~kg}\right.$ ) of water at $0{ }^{\circ} \mathrm{C}$ to ice at $0{ }^{\circ} \mathrm{C}$ over a period of 24 hours.

vii. The cooling load of the machine was approximately $4,500 \mathrm{~W}$.

viii. The cooling load of the refrigerator component of the machine was approximately $253 \mathrm{~W}$.

ix. The refrigerant used was R 22 .

Figure 1 shows the Temperature - Entropy Diagram of the design/concept of the REFACON machine.

Each point designates the start or finish of a process in the vapour compression system.

Point 1 shows refrigerant at the Compressor suction at the refrigerant pure vapour line at $-4{ }^{\circ} \mathrm{C}$ (where gaseous refrigerant is sucked into the compressor)

Point 1a shows refrigerant after suction superheating (where the gaseous refrigerant at point 1 is heated further; superheated). This ensures that only purely vapour/gaseous refrigerant is sucked into the compressor.

Point 2 shows refrigerant after isentropic compression (isentropic compression occurs during compression of refrigerant by the refrigerator compressor. This process is a constant entropy process). At this point the refrigerant is in a superheated phase.

Point 3a shows refrigerant after condensation when the refrigerant has condensed from superheated gas to a purely liquid phase at the design condenser temperature of $40^{\circ} \mathrm{C}$.

Point 3 shows the refrigerant after sub cooling (here the temperature is reduced lower than condenser temperature to $38{ }^{\circ} \mathrm{C}$. This ensures that purely liquid refrigerant is expanded from process 3 to 4 ). Assuming no pressure loss in the condenser, point 4 shows the refrigerant after isentropic expansion from $1,534 \mathrm{kPa}$ to $436.1 \mathrm{kPa}$ as shown in Figure 2. Each point designates the start or finish of a process in the vapour compression system. Point 1 shows refrigerant at the Compressor suction at the refrigerant pure vapour line at $436.1 \mathrm{kPa}$ pressure and $403.5 \mathrm{~kJ} / \mathrm{kg}$ enthalpy. Point 1a shows refrigerant after suction superheating at $436.1 \mathrm{kPa}$ pressure and $406.336 \mathrm{~kJ} / \mathrm{kg}$ enthalpy. Point 2 shows refrigerant after isentropic 
compression at 1,534 $\mathrm{kPa}$ pressure and $438.54 \mathrm{~kJ} / \mathrm{kg}$ enthalpy.

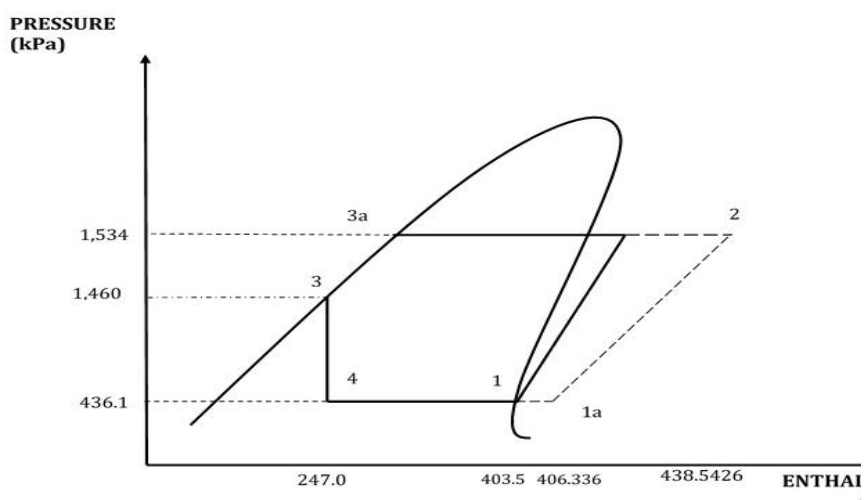

Figure 2: Pressure - Enthalpy Diagram of the design/concept of the REFACON machine.

At this point the refrigerant is in a superheated phase. Point 3a shows refrigerant after isobaric condensation when the refrigerant has condensed from superheated gas to a purely liquid phase at the constant pressure of $1,534 \mathrm{kPa}$.

Point 3 shows the refrigerant after sub cooling along the purely liquid line (here the temperature is reduced lower than the condenser temperature to 38 ${ }^{\circ} \mathrm{C}$ respectively. This ensures that purely liquid refrigerant is expanded under constant enthalpy from process 3 to 4 . Assuming, there is no pressure loss in the condenser, the pressure remains same at 1,534 $\mathrm{kPa})$. Point 4 shows the refrigerant after isenthalpic expansion from $1,534 \mathrm{kPa}$ to $436.1 \mathrm{kPa}$ as shown in Figure 2.

\subsection{Description of the System Components \\ 2.2.1 Mass Flow Rate and Cooling Load}

The mass flow rate of refrigerant in the system, $\dot{m}$ is given in equation (1) as

$$
\dot{\mathrm{m}}=\frac{\text { Cooling Load of REFACON }}{H_{1 a 4}}
$$

$\mathrm{H}_{1 \mathrm{a} 4}$ was obtained from figure 2 by taking the difference between points $1 \mathrm{a}$ and 4 . This shows the refrigeration effect of the system (RE) or heat absorbed by the evaporator of the system.

The Work done by Compressor is given in equation (2) as

$$
W_{12}=H_{1 a 2} \times \dot{\mathrm{m}}
$$

$\mathrm{H}_{1 \mathrm{a} 2}$ was obtained from figure 2 by taking the difference between points 2 and 1 . This shows the heat absorbed by the refrigerant during isentropic compression. $1.5 \mathrm{hp}(1.119 \mathrm{~kW})$ compressor was used. Thus, the effective mass flow rate of the refrigerant (R 22) $\dot{\mathrm{m}}_{\text {eff }}$ is given in equation (3) as,

$$
\dot{\mathrm{m}}_{\text {eff }}=\frac{W_{12}}{H_{12}}
$$

The effective cooling load of the REFACON is given in equation (4) as CL REF

$$
C L_{R E F}=\dot{\mathrm{m}}_{\text {eff }} \times R E
$$

Where RE (Refrigeration Effect $)=159.4336 \mathrm{~kJ} / \mathrm{kg}$

$$
C O P=\frac{R E}{H_{1 a 2}}=\frac{159.4336}{32.109} \approx 4.97
$$

$\mathrm{H}_{23}$ (Heat of Condensation) was obtained from Figure 2 by taking the difference between points 2 and 3 .

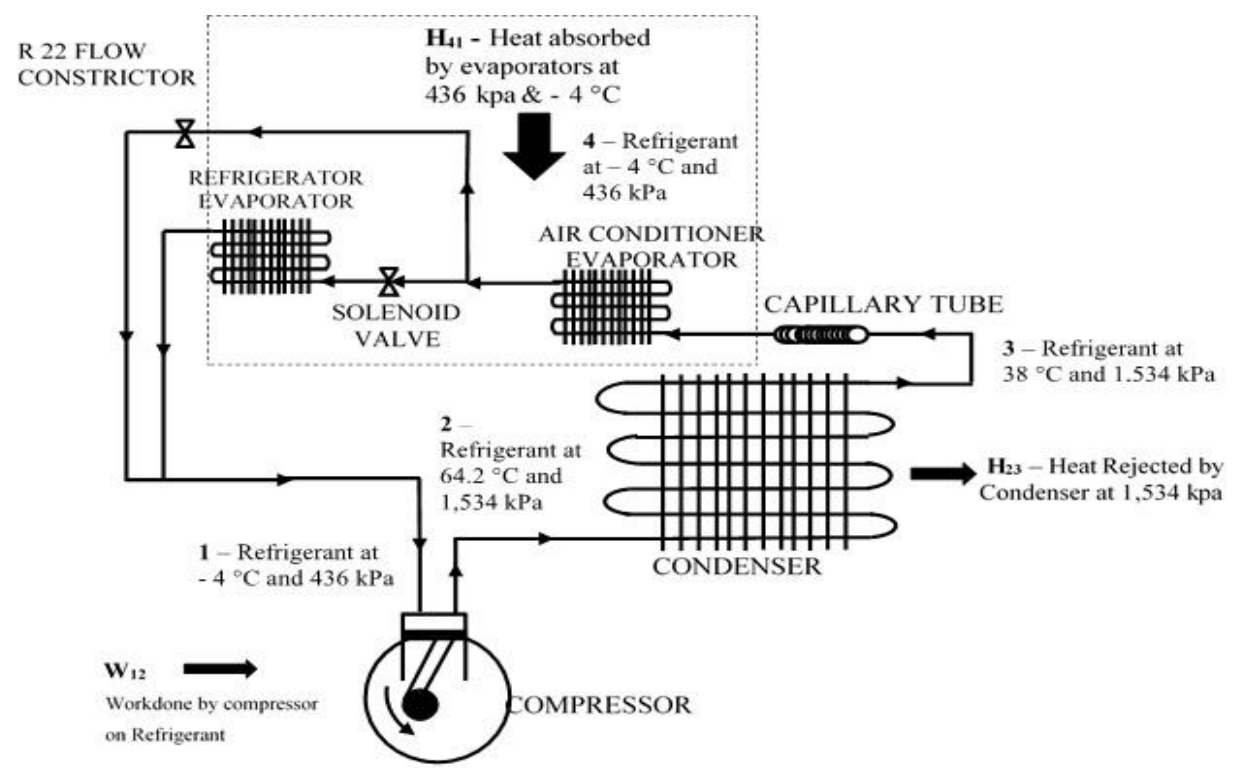

Figure 3 : Schematic diagram of the REFACON Machine with all refrigeration processes 1 to 4 shown and related to Figures 1 and 2. 
$H_{23}$ was determined as $191.5426 \mathrm{~kJ} / \mathrm{kg}$. The heat dissipated by the condenser, $W_{23 \text { (new) }}$

$$
W_{23(n e w)}=H_{23} \times \dot{\mathrm{m}}_{\text {eff }}
$$

The heat rejected by the condenser $W_{23(\text { new })}$ is calculated as $6.673 \mathrm{~kW}$.

Table 1: Revision of the Design parameters with respect to Mass flow rate and Compressor power

\begin{tabular}{|c|c|c|c|}
\hline S/№ & $\begin{array}{l}\text { System } \\
\text { Parameter }\end{array}$ & $\begin{array}{c}\text { Mass Flow } \\
\text { Rate }(\dot{m}= \\
0.0283 \mathrm{~kg} / \mathrm{s})\end{array}$ & $\begin{array}{c}\text { Revised Mass } \\
\text { Flow Rate }\left(\dot{m}_{\text {eff }}=\right. \\
0.03484 \mathrm{~kg} / \mathrm{s})\end{array}$ \\
\hline 1 & $\begin{array}{l}\text { Compressor } \\
\text { Power }\end{array}$ & $\begin{array}{c}907 \text { W (1.22 } \\
\text { hp) }\end{array}$ & $1,119 \mathrm{~W}(1.5 \mathrm{hp})$ \\
\hline 2 & $\begin{array}{l}\text { Heat lost in } \\
\text { condenser }\end{array}$ & $5,410 \mathrm{~W}$ & $6,673 \mathrm{~W}$ \\
\hline 3 & $\begin{array}{l}\text { Refrigerator } \\
\text { Tonnage }\end{array}$ & $773 \mathrm{~W}$ & $953 \mathrm{~W}$ \\
\hline 4 & $\begin{array}{l}\text { Air conditioner } \\
\text { cooling load }\end{array}$ & $3,720 \mathrm{~W}$ & $4,590 \mathrm{~W}$ \\
\hline 5 & Total Cooling load & $4,500 \mathrm{~W}$ & $5,550 \mathrm{~W}$ \\
\hline
\end{tabular}
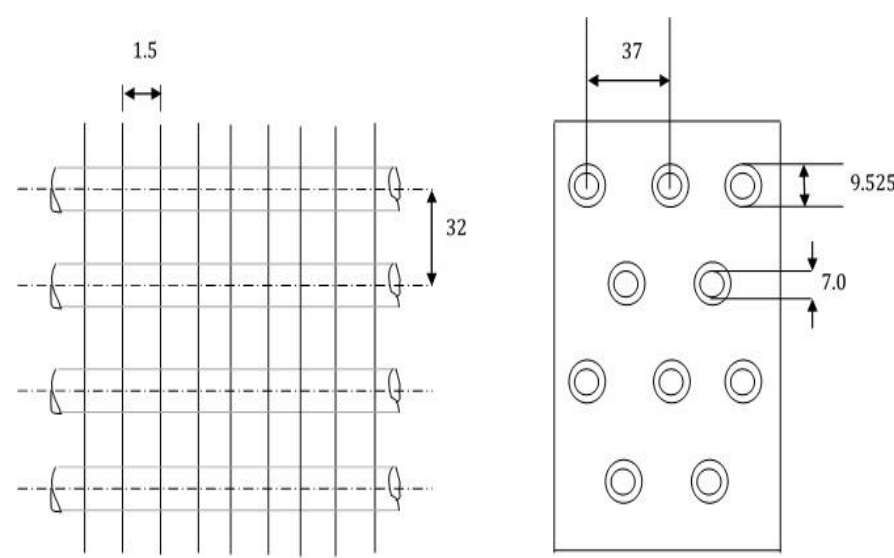

Figure 4: Front and Side view of the condenser All Dimensions in $\mathrm{mm}$

Figure 4 shows the front and side views of the condenser. The thickness of the plate is $0.4 \mathrm{~mm}$

\subsection{Design and Fabrication of the Condenser}

From table 1 above, the heat rejected in the condenser is $6,673 \mathrm{~W}$, so the design shown in figure 4 above was employed. It is a fined tube arrangement with the tubes perpendicular to the air flow between the adjacent plates that act as fins. These fins act as extended surface area to aid cooling and condensation of refrigerant in the tubes.

The configuration seen in Figure 4 above is annular in nature. From the fin analysis carried out, the efficiency was derived as $93 \%$.Applying Akers et al correlation [9] the total surface area of the condenser was calculated as $21.27 \mathrm{~m}^{2}$
The condenser was constructed using $9.525 \mathrm{~mm}$ copper tube and $0.4 \mathrm{~mm}$ thick Aluminium plate as fins (see Figure 4). From total surface area of the condenser, the surface area of the condenser tube was calculated as $0.3096 \mathrm{~m}^{2}$. Hence, condenser duct length is $10,400 \mathrm{~mm}$ while, the Total Surface Area of fins is $20.96 \mathrm{~m}^{2}$.

Copper and aluminium are used because the values for Thermal Conductance and specific heat capacities are high. In addition to that, they are readily available. After fabrication, the condenser was pressure tested and checked for leaks (by charging with gas, measuring the pressure with a manifold gauge and checking the next day if the pressure remained the same or not).

\subsection{Expansion Valve}

From Figure 2, the difference in pressure between the discharge and suction sides $\Delta P$ is given as $1097.9 \mathrm{kPa}$. Applying Darcy Weisenbach equation:

$$
\frac{L}{D_{\text {cap }}}=\frac{2 \Delta P}{\rho_{\text {cap }} \times v_{\text {cap }}^{2} \times f}
$$

Length of capillary duct was $1,700 \mathrm{~mm}$ with an internal diameter of $1.905 \mathrm{~mm}$.

\subsection{Design and Fabrication of Evaporator for Air conditioner segment}

From Table 1, the heat absorbed by the air conditioner evaporator is $4,590 \mathrm{~W}$, so the design shown in Figure 4 was employed. The evaporator is a Fined tube construction using $9.53 \mathrm{~mm}$ Copper tube and $0.4 \mathrm{~mm}$ thick Aluminium plate as fins. A cross section of the evaporator is as shown in Figure 4. The tubes are perpendicular to the air flow between the adjacent plates that act as fins. These fins act as extended surface area to aid boiling and vaporization of refrigerant in the tubes.

The configuration seen in Figure 4 is annular in nature. From the fin analysis carried out, the efficiency was calculated as $93 \%$. The evaporator was designed assuming a face velocity equal to $1.0 \mathrm{~m} / \mathrm{s}$ of air moving over the face of the evaporator. Applying Gnielinski's correlation [9] the total surface area of the evaporator was calculated as $7.174 \mathrm{~m}^{2}$.

The evaporator was constructed using $9.525 \mathrm{~mm}$ copper tube and $0.4 \mathrm{~mm}$ thick Aluminium plate as fins (see Figure 4). From total surface area of the evaporator, the surface area of the evaporator tubes were calculated as $0.1044 \mathrm{~m}^{2}$. Hence from design, evaporator duct length is $3,500 \mathrm{~mm}$ while, the Total

Vol. 35, No. 4, October 2016 
Surface Area of fins is $7.00 \mathrm{~m}^{2}$ from design, the face area of the evaporator is $0.0762 \mathrm{~m}^{2}$.

Copper and aluminium are used because the values for Thermal Conductance and specific heat capacities are high. In addition to that, they are readily available. After fabrication, the evaporator was pressure tested and checked for leaks (by charging with gas, measuring the pressure with a manifold gauge and checking the next day if the pressure remained the same or not).

\subsection{Design and Fabrication of Evaporator for Refrigerator Segment}

In this project, the heat absorbed by the Refrigerator evaporator is $0.253 \mathrm{~kW}$. This value is at variance with $953 \mathrm{~W}$ as seen in table 1 . This is because, the value in table 1, is applicable if the design was for a freezer unit (it will be the amount of heat absorbed to freeze 200 litres of water at $0{ }^{\circ} \mathrm{C}$ over a period of 24 hours). For the project, this is superfluous.

In designing the refrigerator evaporator, the following assumptions were made:

i. The form of heat transfer required inside a refrigerator is mostly Natural Convection.

ii. That the flow inside the refrigerator box was turbulent to aid proper mixing of the air.

iii. That the evaporator was placed at the top of the box in order to aid Natural Convection.

With the above assumptions and with Rayleigh's definition of Turbulent flow: $R a \geq 1 \times 10^{9}$ [13], the required cooling capacity of the refrigerator was derived as $253 \mathrm{~W}$. In order to obtain an evaporator of appropriate design rating, the following are necessary:

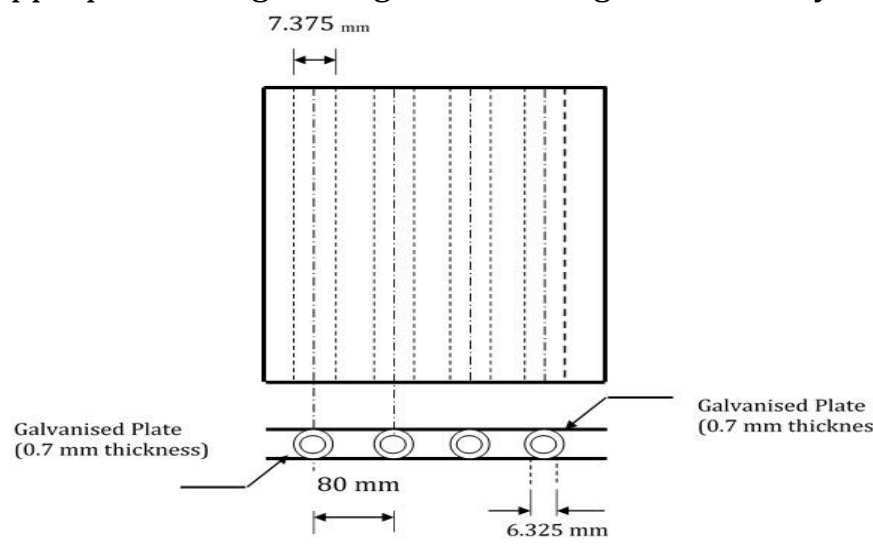

Figure 5: Plan and Side view of the Refrigerator Evaporator

a. The evaporator should be finned to improve efficiency. Preferably, fins are Galvanised Steel plate which act as extended surfaces as shown in Figure 5. b. The pipes are made of copper.

c. The evaporator was designed to operate on Natural Convection.

The calculated evaporator duct length is $5,800 \mathrm{~mm}$; while, the Total Surface Area of fins is $0.926 \mathrm{~m}^{2}$. The Refrigerator Evaporator is a tube enclosed in plate construction. The length of tube $(5,800 \mathrm{~mm})$ was first measured, then using figure 6 as a guide, the pipe was bent with a gap of $80 \mathrm{~mm}$ between each bend.
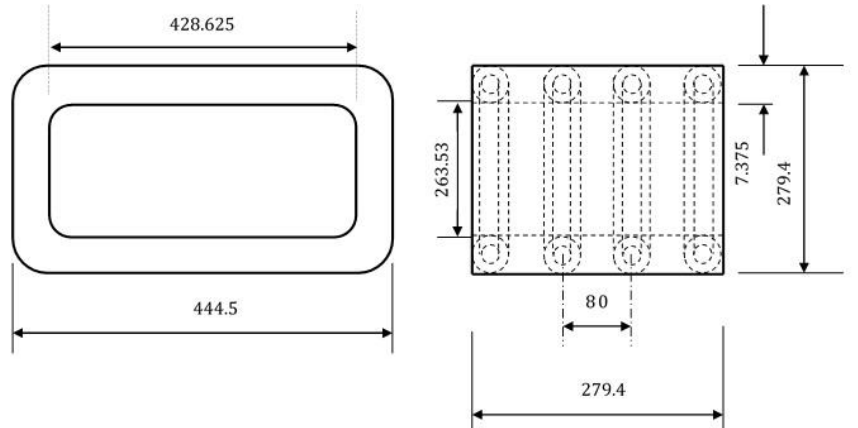

Figure 6: Front and Side view of the Refrigerator Evaporator

\subsection{Indoor Unit Fabrication}

A sheet of Mild Steel plate $2.44 \mathrm{~m} \times 1.22 \mathrm{~m}$ was marked out with the following dimensions:

2 pieces of $1.473 \mathrm{~m} \times 0.61 \mathrm{~m}(58 \times 24)$ inches and 3 pieces of $0.66 \mathrm{~m} \times 0.66 \mathrm{~m}(24 \times 24)$ inches

Once marked out, with scriber and steel rule, they are cut out with a Guillotine machine and all pieces are bent with 1 inch $(25.4 \mathrm{~mm})$ clearance on all sides. These sections are then tacked using an arc welder to form the shape of the indoor unit. The pieces mentioned constitute the vertical sides, top, middle and bottom sections of the indoor unit.

Another sheet of Mild Steel plate $2.44 \mathrm{~m} \times 1.22 \mathrm{~m}$ was marked out with the following dimensions

1 piece of $0.813 \mathrm{~m} \times 0.508 \mathrm{~m}(32 \times 20)$ inches; 1 piece of $0.94 m \times 0.737 m(37 \times 29)$ inches

Once marked out, with scriber and rule, they are cut out with a Guillotine machine and all pieces are bent with 1 inch $(25.4 \mathrm{~mm})$ clearance on all sides.

These sections are then tacked using an arc welder to form the door back panel and door of the indoor unit The dimensions of the refrigerated space is:

Height - 812 mm, Width - $470 \mathrm{~mm}$, Depth - $534 \mathrm{~mm}$ A sheet of Galvanised Steel $2.44 \mathrm{~m} \times 1.22 \mathrm{~m}$ was marked out with the following dimensions:

1 piece of $1.511 \mathrm{~m} \times 0.839 \mathrm{~m}(59.5 \times 33)$ inches, 2 pieces of $0.495 \mathrm{~m} \times 0.533 \mathrm{~m}(19.5 \times 21)$ inches and 1 piece of $0.813 m \times 0.508 m(32 \times 20)$ inches 


\subsection{Charging and Power Testing}

It should be noted that, the machine is the first of its kind, and data on the machines patented by Maniscalco [7] and Ledbetter [8] could not be accessed. Thus, each component had to be individually tested in order to ascertain its performance.

a. In carrying out the charging and power testing, firstly, the machine was purged by expelling any gas trapped in the system. This was done by "pumping down" the system.

b. The discharge and suction valves were then opened to allow free movement of refrigerant.

c. The UNIWELD Manifold gauge with its hoses were connected to the respective discharge and suction valves of the machine. Both gauges were zeroed to prevent faulty read out. The purpose is to measure instantaneous discharge and suction pressures of the machine.

d. A refrigeration canister containing 2 kilogrammes of R 22 refrigerant was placed on a weighing scale. The scale reading was measured to confirm that the mass of refrigerant is $2 \mathrm{~kg}$. A charging hose connected the charging valve of the machine to the $\mathrm{R} 22$ refrigerant canister.

e. Six (6) K - type thermocouples were brazed to the machine at the following points:

(i) Discharge point of the compressor: this is to measure the instantaneous temperature of the refrigerant as it is isentropically compressed during discharge.

(ii) The entry into the condenser: this is to measure the instantaneous temperature of refrigerant before condensation.

(iii) Exit from the condenser: this is to measure the instantaneous temperature of refrigerant after condensation.

(iv) Suction line on the indoor unit: this measures the instantaneous temperature of refrigerant in the suction line of the machine.

(v) Air Conditioner evaporator: this measures the instantaneous temperature of the air conditioner evaporator.

(vi) Refrigerator evaporator: this measures the instantaneous temperature of the refrigerator evaporator.

f. A YEW Portable Single phase Wattmeter was connected across the machine (in parallel to the machine between the live and neutral wires from the electricity mains supply.

g. The machine was then switched on, and the power consumption was noted. h. The machine was charged with refrigerant by opening the gas canister and adhering to the following guidelines:

i. The stable liquid line temperature measured by thermocouple $\mathrm{C}$ in ${ }^{\circ} \mathrm{C}$, did not exceed the saturation temperature at the discharge pressure. Discharge pressure was read off the manifold gauge in $\mathrm{kPa}$. The value obtained was compared with pressure stated in the $\mathrm{R} 22$ Thermodynamic tables. The consequence of this is to ensure that only liquid refrigerant is throttled/expanded.

ii. The stable suction line temperature measured by thermocouple $\mathrm{D}$ in ${ }^{\circ} \mathrm{C}$, exceeded the saturated temperature at the suction line pressure. Suction pressure was read off the manifold gauge in $\mathrm{kPa}$. The value obtained was compared with pressure stated in the $\mathrm{R} 22$ Thermodynamic tables. The consequence of this ensured that any refrigerant in the suction line was superheated and was not in liquid state.

iii. Temperature measured at the compressor discharge by thermocouple $\mathrm{A}$ measured in ${ }^{\circ} \mathrm{C}$, exceeded the saturation temperature at the discharge pressure read off the manifold gauge in bar. This ensures that the pumped refrigerant is in superheated state. This implied that the compressor was functioning properly.

iv. The Air conditioner evaporator temperature measured by thermocouple E, should be lower than the measured suction line temperature measured by thermocouple D.

With the given guidelines, the system was charged with gaseous refrigerant (R 22) until fully charged. Then the scale reading was noted and the mass of refrigerant used was deduced.

With system charged, the reading of the Wattmeter was noted as power consumed by the machine.

In testing the air conditioner component ANSI/ASHRAE Standard 37 - 2009 [14] was used. The test carried out on the machine as described by BSR/ASHRAE Standard 16-1983R is Cooling Capacity Test - Psychometric Test Indoor. In order to carry out this test, a Lutron EM - 9300 SD Environment meter was used.

The meter gave results of the following parameters:

a. Dry bulb temperature of ambient air and dry bulb temperature of conditioned air, measured in ${ }^{\circ} \mathrm{C}$.

b. Wet bulb temperature of ambient air and wet bulb temperature of conditioned air measured in ${ }^{\circ} \mathrm{C}$. 
c. Relative humidity of ambient air and relative humidity of conditioned air, measured in percentage.

d. Velocity of conditioned air measured in $\mathrm{m} / \mathrm{s}$. The results of these tests are shown in table 3.

e. In testing the refrigerator, the minimal temperature measured was recorded and, compared with the design value.

\section{RESULTS AND DISCUSSION}

\subsection{Discussion of its performance}

From the tests carried out in the previous section, the Experimental Pressure - Enthalpy and Temperature Entropy curves of the machine were sketched as seen in figure 7.

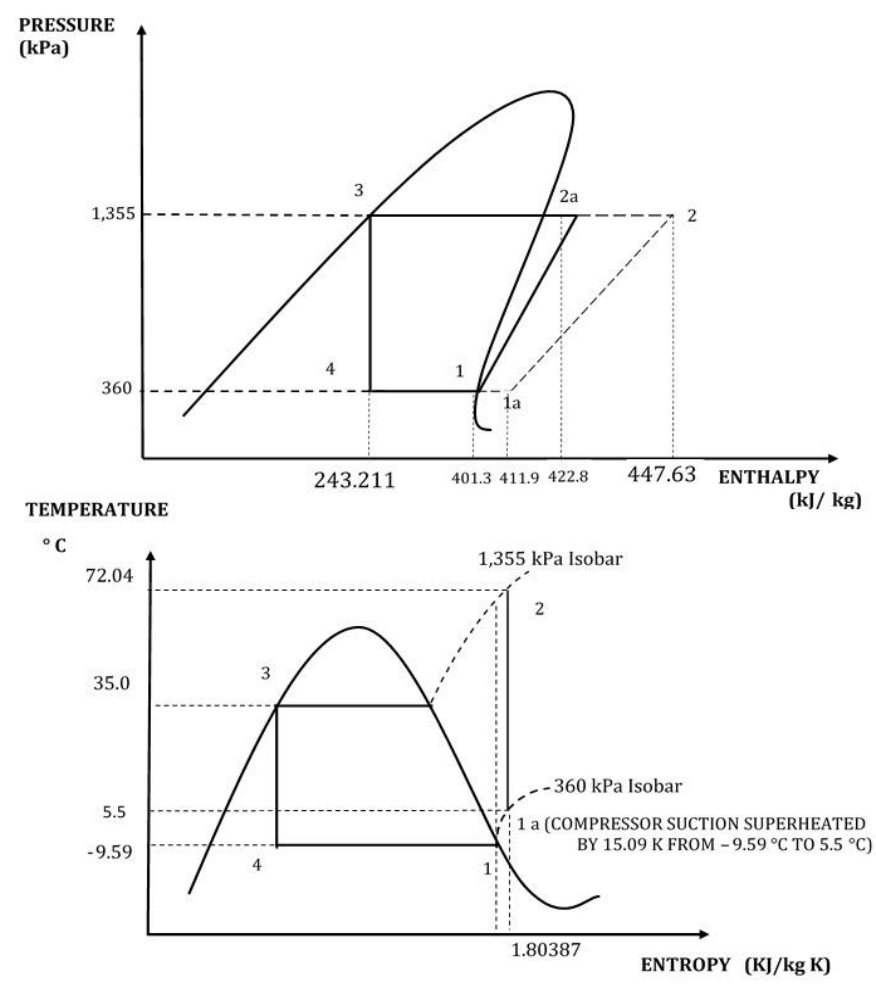

Figure 7: Experimental Pressure-Enthalpy and Temperature-Entropy Curves of the REFACON

From Figure 7, the following can be observed:

i. Between 1 and 1a: At the experimentally measured suction pressure $(360 \mathrm{kPa})$, according to $\mathrm{R} 22$ Thermodynamic tables, the saturated liquid temperature recorded was $-9.59{ }^{\circ} \mathrm{C}$. However, the temperature recorded on the suction line was 5.5 ${ }^{\circ} \mathrm{C}$. This implies a suction superheat of $15.09 \mathrm{~K}$ as compared to $4 \mathrm{~K}$ allowed for in the design.

ii. Between $1 \mathrm{a}$ and 2: The refrigerant was isentropically compressed from $360 \mathrm{kPa}$ to 1,355 $\mathrm{kPa}$. These values of suction and discharge pressures were read off the manifold gauges. After compression, the instantaneous temperature of the refrigerant measured by thermocouple A was $72.04{ }^{\circ} \mathrm{C}$. Using R 22 Thermodynamic tables, the change in enthalpy of $35.73 \mathrm{~kJ} / \mathrm{kg}$ was measured during compression.

iii. Between 2 and 3: The refrigerant was condensed at constant pressure of $1,355 \mathrm{kPa}$ from $72.04{ }^{\circ} \mathrm{C}$ to $35.0^{\circ} \mathrm{C}$, with a change in enthalpy of $203.58 \mathrm{~kJ} / \mathrm{kg}$. But, the actual heat rejected by the condenser is 2a to 3, a change in enthalpy of $179.59 \mathrm{~kJ} / \mathrm{kg}$. Thermocouple $\mathrm{B}$ measured the temperature of Point $2 \mathrm{a}$ as $43.0{ }^{\circ} \mathrm{C}$. By use of $\mathrm{R} \quad 22$ Thermodynamic tables, the enthalpy at $2 \mathrm{a}$ was obtained on the Pressure - Enthalpy diagram. As seen, Point 3 sits on the liquid line of the pressure - enthalpy diagram, indicating that the refrigerant was fully condensed and purely liquid. However, the refrigerant did not sub-cool. Sub - Cooling reduces entropy, aids expansion and will provide a larger Refrigeration Effect.

iv. Between 3 and 4: The refrigerant was isentropically expanded from $1,355 \mathrm{kPa}$ to $360 \mathrm{kPa}$. The stable liquid temperature of $\mathrm{R} 22$ at $360 \mathrm{kpa}$ is $-9.59^{\circ} \mathrm{C}$. The temperature measured by thermocouple $\mathrm{E}$ when the air conditioner blower was off was -9.5 ${ }^{\circ} \mathrm{C}$.

v. Between 4 and 1: The refrigerant was vaporized and heated at constant pressure of $360 \mathrm{kPa}$ from $9.59{ }^{\circ} \mathrm{C}$ to $5.5^{\circ} \mathrm{C}$, with a change in enthalpy of $168.69 \mathrm{~kJ} / \mathrm{kg}$. This change in enthalpy is also known as the Refrigeration Effect (RE).

vi. From (ii) above, the actual mass flow rate of the system can be calculated (see equation 3 ). Since $\mathrm{W}_{12}$ (Power of the compressor) is $1.119 \mathrm{~kW}$, the Refrigeration Effect is $168.69 \mathrm{~kJ} / \mathrm{kg}$, the revised flow rate of refrigerant $\mathrm{R} 22$ ( $\dot{\mathrm{m}}_{\text {new }}$ ) is obtained as $0.03118 \mathrm{~kg} / \mathrm{s}$ as shown in Table 2 .

Also, observing item 15 on the Table 2; $\mathrm{RE}=168.69$ $\mathrm{kJ} / \mathrm{kg}$, when multiplied by Revised mass flow rate of refrigerant in the system $\left(\dot{\mathrm{m}}_{\text {new }}\right)$, the effective cooling load of the system is obtained from equation 8.

$$
Q_{R E F A C O N}=\dot{\mathrm{m}}_{\text {new }} \times R E=5.28 \mathrm{~kW}<5.55 \mathrm{~kW}
$$

\subsection{Performance of the Heat Exchangers}

\subsubsection{Condenser}

With reference to the design, the heat dissipated by the condenser is $6.673 \mathrm{~kW}$. In order to obtain a condenser of appropriate design rating, the following were done:

a. The condenser was finned to improve efficiency. It was designed using aluminium plate as fins

b. The pipes were made of copper. 
c. The condenser was forced draught aided by electric fan to improve heat dissipation.

The performance of the condenser can be determined by measuring the temperature of refrigerant in and out of the condenser. The high side pressure read from the Manifold Gauge during the experiment was $1,355 \mathrm{kPa}$. The temperature of refrigerant at the condenser outlet as read from the $\mathrm{K}$ type thermocouple was $35^{\circ} \mathrm{C}$. Temperature of refrigerant entering the condenser as read from the $\mathrm{K}$ type thermocouple was $43{ }^{\circ} \mathrm{C}$. From, R22 Thermodynamic tables, the difference in enthalpy of refrigerant observed in the condenser $\left(\mathrm{H}_{2 \mathrm{a} 3}\right)$ is obtained as $179.59 \mathrm{~kJ} / \mathrm{kg}$.

In order to calculate the actual heat rejected in the condenser, the actual mass flow rate (revised mass flow rate)of the system must be known as it was obtained as $0.03118 \mathrm{~kg} / \mathrm{s}$ as shown in Table 2.Thus, observable heat rejected in the condenser was calculated as $5,622 \mathrm{~W}$.

The variation in between the design and experimental value can be explained through the phenomenon of Thermal Contact Resistance. This is defined as the thermal resistance observed between the junction of two composite materials. It can be negated, by using a joining material of high thermal conductivity.

However, during the design, it was ignored because, the materials used for the condenser naturally possess high thermal conductivities.

\subsubsection{Air Conditioner Evaporator}

With reference to the design, the heat absorbed by the air conditioner evaporator is $4.59 \mathrm{~kW}$. In order to obtain an evaporator of appropriate design rating, the following were done:

a. The evaporator was finned using aluminium plate to improve efficiency.

b. The pipes were made of copper.

c. The evaporator is forced draught with electric fan to improve heat absorption.

d. Using the Lutron EM 9300 - SD Environment meter and in compliance with the prescribed ANSI/ASHRAE Standard 37 - 2009 tests for unitary air conditioners the values in table 3 were obtained.

e. From results obtained, as shown in table 2, the evaporator absorbed 5,179 $\mathrm{W}$ of heat from the air that it conditioned.

f. Heat Absorbed by the Evaporator is as given by [14] is shown in equation (9)

$$
Q=\frac{q_{\text {air }}\left(\Delta h_{\text {air }}\right)}{v_{n}}
$$

Table 2: Comparison between the Design and the Experimental Values obtained

\begin{tabular}{|c|c|c|c|}
\hline $\begin{array}{l}\text { S/ } \\
\text { № }\end{array}$ & Machine Property & $\begin{array}{l}\text { Design } \\
\text { Value }\end{array}$ & $\begin{array}{c}\text { Experimental } \\
\text { Value }\end{array}$ \\
\hline 1 & $\begin{array}{l}\text { High Side/Discharge } \\
\text { Pressure }\end{array}$ & $1,534 \mathrm{kPa}$ & $1,355 \mathrm{kPa}$ \\
\hline 2 & $\begin{array}{l}\text { Condenser Inlet } \\
\text { Temperature }\end{array}$ & $64.22{ }^{\circ} \mathrm{C}$ & $43^{\circ} \mathrm{C}$ \\
\hline 3 & $\begin{array}{l}\text { Condenser Outlet } \\
\text { Temperature }\end{array}$ & $38^{\circ} \mathrm{C}$ & $35^{\circ} \mathrm{C}$ \\
\hline 4 & $\begin{array}{l}\text { Low Side/ Suction } \\
\text { Pressure }\end{array}$ & $436 \mathrm{kPa}$ & $360 \mathrm{kPa}$ \\
\hline 5 & $\begin{array}{l}\text { Suction Inlet } \\
\text { Temperature }\end{array}$ & $0^{\circ} \mathrm{C}$ & $5.5^{\circ} \mathrm{C}$ \\
\hline 6 & Suction Superheat & $4 \mathrm{~K}$ & $15 \mathrm{~K}$ \\
\hline 7 & $\begin{array}{l}\text { Discharge Sub- } \\
\text { Cooling }\end{array}$ & $2 \mathrm{~K}$ & $0 \mathrm{~K}$ \\
\hline 8 & $\begin{array}{l}\text { Refrigerator } \\
\text { Temperature }\end{array}$ & $-4{ }^{\circ} \mathrm{C}$ & $8^{\circ} \mathrm{C}$ \\
\hline 9 & $\begin{array}{l}\text { Air Conditioner } \\
\text { Evaporator Temp }\end{array}$ & $-4{ }^{\circ} \mathrm{C}$ & $5^{\circ} \mathrm{C}$ \\
\hline 10 & $\begin{array}{l}\text { Air Conditioner CMPS } \\
\text { (Cubic metre/second) }\end{array}$ & $0.0762 \frac{\mathrm{m}^{3}}{\mathrm{~s}}$ & $0.1905 \frac{\mathrm{m}^{3}}{\mathrm{~s}}$ \\
\hline 11 & $\begin{array}{l}\text { Mass of Refrigerant } \\
\text { used }\end{array}$ & & $0.620 \mathrm{~kg}$ \\
\hline 12 & Mass flow Rate (m) & $0.02823 \mathrm{~kg} / \mathrm{s}$ & $0.0267 \mathrm{~kg} / \mathrm{s}$ \\
\hline 13 & $\begin{array}{l}\text { Revised Mass flow } \\
\text { rate (安new) }\end{array}$ & $0.03484 \mathrm{~kg} / \mathrm{s}$ & $0.03118 \mathrm{~kg} / \mathrm{s}$ \\
\hline 14 & $\begin{array}{l}\text { Coefficient of } \\
\text { Performance (COP) }\end{array}$ & 4.97 & 4.72 \\
\hline 15 & $\begin{array}{l}\text { Refrigeration Effect } \\
(\mathrm{RE})\left(\mathrm{H}_{14}\right)\end{array}$ & $\begin{array}{c}159.4336 \\
\mathrm{~kJ} / \mathrm{kg}\end{array}$ & $168.69 \mathrm{~kJ} / \mathrm{kg}$ \\
\hline 16 & Condenser Size $\left(\mathrm{W}_{23}\right)$ & $6,673 \mathrm{~W}$ & $6,680 \mathrm{~W}$ \\
\hline 17 & $\begin{array}{l}\text { Observed Condenser } \\
\left.\text { Heat }\left(\mathrm{W}_{2 \mathrm{a}}\right)\right) \\
\text { Air Conditioner }\end{array}$ & & $5,622 \mathrm{~W}$ \\
\hline 18 & $\begin{array}{l}\text { Evaporator Size } \\
\text { (Derived from table } 1 \\
\text { and table 3) }\end{array}$ & $4,590 \mathrm{~W}$ & $5,179 \mathrm{~W}$ \\
\hline
\end{tabular}

Table 3: Performance of the Air Conditioner

\begin{tabular}{lccc}
\hline Property & $\begin{array}{c}\text { Ambient Air } \\
\text { Conditions }\end{array}$ & $\begin{array}{c}\text { Conditioned } \\
\text { Air }\end{array}$ & $\begin{array}{c}\text { Difference } \\
\text { Due to } \\
\text { Cooling }\end{array}$ \\
\hline $\begin{array}{l}\text { Dry Bulb } \\
\text { Temperature }\end{array}$ & $27.5^{\circ} \mathrm{C}$ & $20.0^{\circ} \mathrm{C}$ & $7.5^{\circ} \mathrm{C}$ \\
$\begin{array}{l}\text { Relative } \\
\text { Humidity }\end{array}$ & $81 \%$ & $89 \%$ & $18 \%$ \\
$\begin{array}{l}\text { Wet Bulb } \\
\begin{array}{l}\text { Temperature } \\
\text { Humidity Ratio }\end{array}\end{array}$ & $24.85^{\circ} \mathrm{C}$ & $18.73{ }^{\circ} \mathrm{C}$ & $6.12{ }^{\circ} \mathrm{C}$ \\
$\begin{array}{l}\text { (X) } \\
\text { Specific } \\
\text { Enthalpy }\end{array}$ & $19.61 \mathrm{~g} / \mathrm{kg}$ & $13.53 \mathrm{~g} / \mathrm{kg}$ & $6.08 \mathrm{~g} / \mathrm{kg}$ \\
\hline
\end{tabular}

In (9) $Q$ is the Heat absorbed (W), $q_{\text {air }}$ is the volumetric flow rate of air through the evaporator $\mathrm{V}_{\mathrm{A}}$ is:

$V_{A}=A_{\text {face(evaporator })} \times v_{\text {air }}\left(\mathrm{m}^{3} / \mathrm{s}\right)$ 
$\Delta h_{\text {air }}$ is change in enthalpy of air during cooling $\mathrm{kJ} / \mathrm{kg}$, and $V_{n}$ is the specific volume of the moist air on a dry air basis of the conditioned $\operatorname{air}\left(\mathrm{m}^{3} / \mathrm{kg}\right)$.

From [14]:

$$
\begin{aligned}
v_{n}=0.287042 & \left(T_{D B}\right. \\
& +273.15) \frac{(1+1.607858 X)}{p}
\end{aligned}
$$

Where: $\mathrm{X}$ is Humidity Ratio (kg of moisture/kg of dry air), $p$ is Standard Atmospheric pressure $(\mathrm{Pa}), \mathrm{T}_{\mathrm{DB}}$ is Dry Bulb temperature of the conditioned air $\left({ }^{\circ} \mathrm{C}\right)$

From (11) $v_{n}=0.00085 \mathrm{~m}^{3} / \mathrm{kg}$

From air conditioner evaporator design, $A_{\text {face(evaporator) }}=0.0762 \mathrm{~m}^{2}, \quad v_{\text {air }}$ from tests performed $=2.5 \mathrm{~m} / \mathrm{s}, \Delta h_{\text {air }}$ and $\mathrm{X}$ were obtained from Psychometric chart [15]

$\mathrm{Q}=5.179 \mathrm{~kW}$ as compared with the design value of $4.59 \mathrm{~kW}$.

From the values obtained, it can be deduced from its performance, that the Air Conditioner Evaporator is larger than required especially as regards to the amount of air handled. Before development, the Air conditioner evaporator was designed for an air flow velocity of $1 \mathrm{~m} / \mathrm{s}$, however, the fan used had an air flow velocity of $2.5 \mathrm{~m} / \mathrm{s}$. Since, the evaporator face area is $0.0762 \mathrm{~m}^{2}$, the actual volumetric flow rate of air through the evaporator is $0.1905 \frac{\mathrm{m}^{3}}{\mathrm{~s}}$ instead of $0.0762 \frac{\mathrm{m}^{3}}{\mathrm{~s}}$ as designed.

From Table 2, the Refrigeration Effect of the machine $167.69 \mathrm{~kJ} / \mathrm{kg}$. This gives an overall cooling effect of $5,280 \mathrm{~W}$. Of this, $5.179 \mathrm{~kW}$ was absorbed by the Air conditioner. Leaving $101 \mathrm{~W}$ for the Refrigerator.

\subsubsection{Refrigerator Evaporator:}

The refrigerator evaporator was designed using Galvanised Steel instead of Aluminium due to non- availability of the specific thickness required. Thus, the performance of the refrigerator is below what is desired. The cooling capacity of the refrigerator is 101 $\mathrm{W}$ (the design value is $253 \mathrm{~W}$, showing a deficit of 152 W). $0.7 \mathrm{~mm}$ Galvanised Steel was used, leading to a poor absorption of heat by the refrigerator evaporator and its low performance.

\subsection{Comparing the Overall System Performance with other Modern Air conditioners}

REFACON was compared with the performance of other air conditioners of similar compressor size and electrical configuration. Data on dual purpose machines of this sort/kind were not available when writing this paper. The result of the comparison is shown in Table 4. The data shown in Table 4, was gleaned from the websites of the air conditioners mentioned. However, the COP was calculated by dividing output cooling by $1.119 \mathrm{~kW}(1.119 \mathrm{~kW}$ is power rating of the compressor used).

According to the Bureau of Energy Efficiency (BEE) of India [16]. The REFACON, with an Energy Efficiency Ratio of 3.911 falls within the range of $>2.2$ which is the benchmark for effective performance of Air conditioners. That gives it a pass rating.

\section{CONCLUSIONS AND RECOMMENDATIONS}

\subsection{Conclusions}

It should be stated, that the REFACON Machine is the first attempt at making dual purpose machine since Ledbetter [8] patented his design in 1989. Tests carried out by Ledbetter [8] or Maniscalco [7], are not available at this time since they are both patents. The REFACON machine was designed as a Dual Purpose Refrigeration system for both comfort cooling (air conditioning) and food storage (refrigeration).

Table 4: REFACON compared with some other Air Conditioners with compressors rated for 1.119kW (1.5hp)

\begin{tabular}{llcccccc}
\hline S/№ & \multicolumn{1}{c}{ Machine } & $\begin{array}{c}\text { Output } \\
\text { Cooling }\end{array}$ & $\begin{array}{c}\text { Input } \\
\text { Power }\end{array}$ & $\begin{array}{c}\text { Power Supply } \\
1 / 220-240 / 50 \\
(\Phi / \mathrm{V} / \mathrm{Hz})\end{array}$ & $\begin{array}{c}\text { EER } \\
(\mathrm{W} / \mathrm{W})\end{array}$ & $\begin{array}{c}\text { Air flow } \\
\text { Rate } \mathrm{m}^{3} / \mathrm{s}\end{array}$ & COP \\
\hline 1 & LG Model & $4.98 \mathrm{~kW}$ & $1.82 \mathrm{~kW}$ & 0.208 & 4.45 \\
2 & SC186HC & $\begin{array}{l}1 / 230 / 50 \\
(\Phi / \mathrm{V} / \mathrm{Hz})\end{array}$ & 2.97 & 0.16 & 3.23 \\
& $\begin{array}{l}\text { Panasonic CW- } \\
\text { XC125VPH }\end{array}$ & $3.611 \mathrm{~kW}$ & $1.21 \mathrm{~kW}$ & $\begin{array}{c}1 / 220-240 / 50 \\
(\Phi / \mathrm{V} / \mathrm{Hz})\end{array}$ & 3.01 & & 4.84 \\
4 & Samsung AS19UGP & $5.418 \mathrm{~kW}$ & $1.8 \mathrm{~kW}$ & $\begin{array}{c}1 / 208-230 / 50 \\
(\Phi / \mathrm{V} / \mathrm{Hz})\end{array}$ & 3.911 & 0.1905 & 4.72 \\
\hline
\end{tabular}


From tests carried out and the results obtained, the following conclusions were made:

i. The REFACON functioned effectively as an air conditioner. The refrigerator and air conditioner components effectively functioned independently as separate parts of the REFACON. The refrigerator performance could have been better, if aluminium was used in constructing the refrigerator evaporator instead of galvanised steel.

ii. The REFACON, with a COP of 4.72 and overall cooling effect of $5,280 \mathrm{~W}$; consumed $1,350 \mathrm{~W}$. The EER of 3.911 measured/derived implies a better efficiency than the other machines compared with.

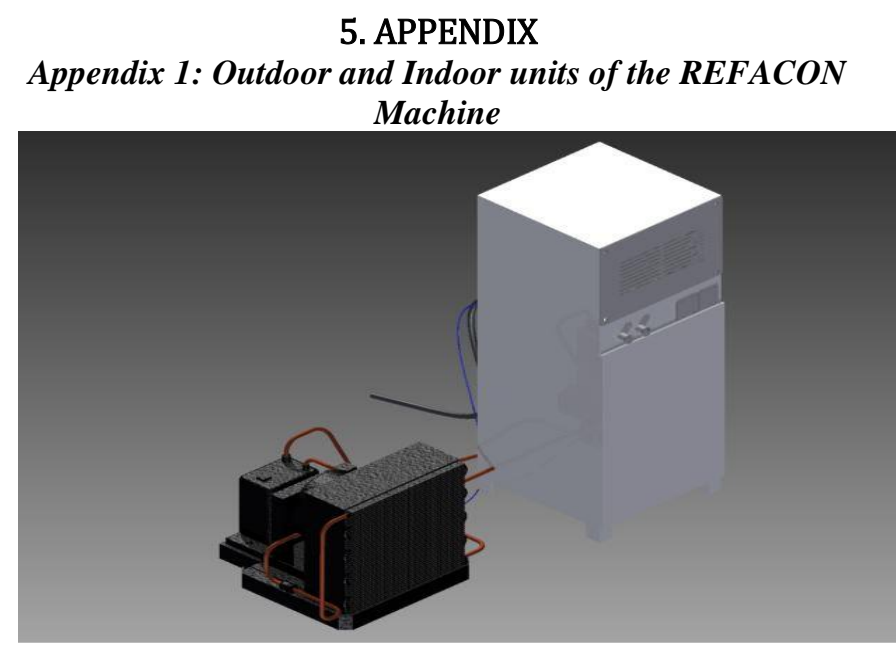

\section{REFERENCES}

[1]. Hundy, G. F., Trott, A.R. and Welch, T. C. Refrigeration and Air Conditioning, Butterworth Heinenmann, Amsterdam, (2008).

[2]. Jones, W.P. Air Conditioning Engineering, Butterworth-Heinenmann, Amsterdam, (2001).

[3]. Oddiah, P.A., Refrigeration [unpublished lecture notes]. GET 222: SWEP, University of Ilorin, 1997/1998 Session

[4]. Wolf, W.F., Refrigerating Apparatus. US Patent: US 1,126,605 (1913),

[5]. Bechtold and Mellowes, Cooling Apparatus. US Patent: US 1,276,612A. (1915).

[6]. Carrier, W.H., Method of Humidifying Air and controlling the humidity and temperature thereof. US Patent: US 1,085,971A. (1913).

[7]. Maniscalco, P. Combination Air Conditioner and Refrigerator. US Patent: US 2,249,772. (1941).
[8]. Ledbetter, R. G. Air-Conditioning Refrigerator. US Patent: US 4,821,530. (1989),

[9]. Wei, W, Fang, X. and Shi, R, "A Comparative Study of Heat Transfer Coefficients for Film Condensation", Energy Science and Technology, Vol. 3 (1) 1 - 9. (2012).

[10].Subramaniam, R. S. "Heat transfer in flow conduits" Lecture Note Department of Chemical and Biomolecular Engineering, Clarkson University. Available from: http://web2.clarkson.edu/projects/subramanian/c h330/notes/Heat\%20Transfer\%20in\%20Flow\%20 Through\%20Conduits.pdfaccessed on Friday, $30^{\text {th }}$ May, (2014).

[11].Bhaita, A. "Cooling Load Calculations and Principles". M06-004 Lecture Note. Continuing Education and Development, 9 Greyridge Farm Court, Stony Point, NY 10980. Available from: http://www.cedengineering.com/upload/cooling\% 20load\%20calculations $\% 20$ and $\% 20$ principles.pdfa ccessed on $30^{\text {th }}$ May, 2014. (2010).

[12].ANSI/ASHRAE: Standard 55 Thermal Environmental Conditions for Human occupancy, American Society of Heating, Refrigerating and Airconditioning Engineers, Atlanta, Georgia, USA (2004).

[13].Bergman, T. L ,Lavine, A. S., Incropera, F.P. and Dewitt, D.P. Fundamentals of Heat and Mass Transfer, John Wiley and Sons Inc., New Jersey. (2011).

[14].ANSI/ASHRAE:. Standard 37 Methods of Testing for Rating Electrically Driven Unitary Air - conditioning and Heat Pump Equipment, American Society of Heating, Refrigerating and Air - conditioning Engineers, Atlanta, Georgia, USA. (2009).

[15].ASHRAE: Psychometric Chart Number 1, American Society of Heating, Refrigerating and Airconditioning Engineers, Atlanta, Georgia, USA. (1992).

[16] Bureau of Energy Efficiency, Guide on Energy Efficient Room Air conditioner. Available from: http://www.beeindia.in/schemes/documents/ecbc Leco3/SnL/Guide\%20on\%20EnergyEfficient\%20Room\%20Air\%20Conditioner.pdfacce ssed on $4^{\text {th }}$ July, (2015).

\section{ACKNOWLEDGEMENT}

Special thanks to my friend, Samuel Oluseyi Oyewole, who connected the wires, set up the controls and powered up the REFACON. 